\title{
Practical Advice for Teaching of University Students the Mechanisms of Self-Government of Safe Behavior
}

\author{
Rashad A. Kurbanova, Ramin Afad oglu Gurbanov ${ }^{\text {, }}$, Asiya M. \\ Belyalova $^{c}$, Elvira V. Maksimova ${ }^{d}$, Irina A. Leonteva ${ }^{e}$ and Ivan A. \\ Sharonov
}

aPlekhanov Russian University of Economics, RUSSIA; 'Institute of Philosophy and Law of National Academy of Sciences of Azerbaijan, AZERBAIJAN; Institute of Legislation and Comparative Law under the Government of the Russian Federation, RUSSIA; 'Kazan (Volga region) Federal University, RUSSIA; ' Chuvash State University, RUSSIA; fUlyanovsk State Agricultural Academy named after P. A. Stolypin, RUSSiA

\section{ABSTRACT}

The relevance of the study is conditioned by the re-estimation of values in modern society and a new understanding of security issues. As a result, security has acquired a complex structure, including the security of the individual in the process of life activity, protection of natural environment (biosphere), national security and global security. The purpose of the paper is to develop practical advice for teaching of university students the mechanisms of self-government of safe behavior. The leading approach to the study is the personal-activity-based approach, which allows considering the mechanisms of self-government of safe behavior of the individual as a set of techniques and methods of self-protection of the vital interests and countering the dangers and threats. The study involves 500 teachers, 500 students who have defined the criteria for effective mechanisms of self-government of safe behavior. The main results of the study is the development of mechanisms to counter the negative information and psychological effects (cognitive, emotional, behavioral) and mechanisms of information-psychological self-protection implemented in the unconscious, the subconscious, the conscious level. The significance of the results obtained is in the fact that the developed mechanisms for countering negative information and psychological influences contribute to the effectiveness of coping behavior, achieved by specially organized activity to overcome the dangers and threats and ensure personal safety. Mechanisms of information-psychological self-protection provide protection of the individual from the internal psychological discomfort or external psychological impact, cause the formation and development of adequate information and a rough basis of life activity.

KEYWORDS

Security of the person, coping behavior, informationpsychological self-defense
ARTICLE HISTORY

Received 16 July 2016

Revised 14 September 2016 Accepted 11 November 2016

\section{CORRESPONDENCE R. A. Kurbanov mos-ssp@mail.ru}

\section{(c) 2017 R. A. Kurbanov et al.}

Open Access terms of the Creative Commons Attribution 4.0 International License apply. The license permits unrestricted use, distribution, and reproduction in any medium, on the condition that users give exact credit to the original author(s) and the source, provide a link to the Creative Commons license, and indicate if they made any changes. (http://creativecommons.org/licenses/by/4.0/) 


\section{Introduction}

The relevance of the study is conditioned by the re-estimation of values in modern society and a new understanding of security issues. As a result, security has acquired a complex structure, including the security of the individual in the process of life activity, protection of natural environment (biosphere), national security and global security. Study of dictionaries reveals that the concept of "security" is associated not so much "with the lack of threat" but as a condition of human feelings and emotions. The Great Dictionary of Russian language defines the security as the absence of danger, threat, safety (Kuznetsov, 2000), and the risk as the threat of disaster, unhappiness and catastrophe (Kuznetsov, 2000). Thus, for human the security is experienced primarily as a sense of security from the effects of various kinds of dangers. Security is one of the basic needs of the individual (Lunev \& Pugacheva, 2014). Like the physiological needs, A.G. Maslow (1959) believes, desires may also dominate in the body. They may usurp the right to organize behavior, subordinating all the opportunities of the body, aiming them to achieve security, and in this case one can rightfully consider the body as an instrument for security providing. Just as in the case of physiological urge, one can say that the receptors, effectors, intelligence, memory, and all the others of individual's abilities are transformed in a given situation into the instrument for providing of security. Just as in the case of a hungry man, the main goal not only determines the perception of the individual, but also determines its philosophy of the future, philosophy of values. For such a person there is no more pressing need than the need for security (sometimes even physiological needs, if they are satisfied, they are regarded as minor, inconsequential). If this state gains extreme force, or becomes chronic, then we say that a man thinks only about security: stability; protection; freedom from fear, anxiety and chaos; Law and order (Maslow, 1959). American psychologist K. Horney (1991) also considers safety as one of the basic needs of the individual. According to K. Horney (1991), in order to achieve security in the world the person uses one of the three basic strategies of interaction with other people: focus on the people, from the people and against the people. Each strategy is the optimization of interpersonal relationships in order to achieve a sense of security in the world around. In other words, the effect of the strategy is to reduce the more or less acceptable life. In addition, each of them is accompanied by a certain basic orientation in relations with other people (Horney, 1991). The threat of terrorism claims a new look at security as a condition of protection of the vital interests of the individual, society and state from internal and external threats. Personality has become the main target of security. And the security of the person is direction for activity of state and public institutions, citizens (Tsygankov, 2010). However, the person must be aware of the need for security, and to position itself as its subject, clearly predict the consequences of his or her actions (Tsyrdya \& Ursul, 2016). The purpose of paper is to develop practical advice for teaching of university students the mechanisms of self-government of safe behavior.

\section{Research methodology}

The leading approach to the study is the personal-activity-based approach, which allows considering the mechanisms of self-government of safe behavior of the individual as a set of techniques and methods for self-protection of the vital interests and countering the dangers and threats. Safety is a priority vital human need (Murray, 2007). The need of the individual in the security is connected with the hazard and risk 
in the course of its activity. The signal of a danger for human is fear as emotional process of a particular subjective experience of the situation in which calmness is under threat. The threat is a situational characteristic of activity consisting in the uncertainty of its outcome and the possible adverse consequences in case of failure (Schneier, 2003). Thus, the person can feel own safety on the basis of subjective cognitive and emotional evaluation of the situation as potentially dangerous, uncertain (Horney, 2000). This assessment is based on the natural signals of danger (pain, loneliness) and the results of a special form of learning (social borrowing). Mastering the mechanisms of self-government of safe behavior allows to be active in a dangerous world, and provides protection of the individual (Petrova et al., 2016). Man is an active social subject and all its vital activity is conscious. Studies of N.A. Abulkhanova-Slavskaya (1980), A.N. Leontjev (1975), A.V. Petrovsky \& M.G. Yaroshevsky (2001) emphasize that every human activity as the entity includes those or other mental processes and is governed by them. Indeed, a person acts as a regulator of its mental capabilities and consciousness determines its quality (Pugacheva et al., 2016). Therefore, we believe the personal-activity-based approach as the methodological basis for the study of human security issues. A combination of methods was used in the research process: theoretical (analysis, synthesis, generalization and systematization), sociological (observation, interviews, questionnaires, expert estimation).

\section{Results}

The main results of this study are: 1) the individual's countering mechanisms against negative information and psychological influence; 2) mechanisms for information-psychological self-defense; 3) criteria for effective mastering the mechanisms of self-government of safe behavior.

\section{Individual's countering mechanisms against negative information and}

\section{psychological influence (cognitive, emotional, behavioral)}

It is found that the cognitive mechanisms include: concentration of attention, selfhypnosis, ideomotor training, conscious self-control, information integration, selfmonitoring, self-awareness, self-perception, the formation sanus-genetic thinking, change of attitudes, removing of the "lack of information» (Lunev \& Pugacheva, 2014). Emotional mechanisms combine: search for support, positive revaluation, creating of sensory images, muscular self-control, autogenic training, self-disclosure (Lunev \& Pugacheva, 2013). Behavioral mechanisms are confrontation, alienation, cooperation, competition, compromise, avoidance, acceptability, role play, self-individualization, deindividualization, self-presentation, self-identification, social borrowing (Lunev, Pugacheva \& Stukolova, 2014).

It is found that the identity's mechanisms to counter the negative information and psychological influences contribute to the effectiveness of coping behavior of the individual in situations of negative information influence. The problem of person's "coping" with difficult life situations attracted the attention of science in the second half of the twentieth century. Initially, the concept of "coping behavior" was used in the psychology of stress and was defined as the sum of the cognitive and behavioral efforts expended by the individual to mitigate the effect of stress (Wasserman et al., 2009). Today, the concept of "coping behavior" has become a meta-subject. We believe that coping behavior can be viewed as a response style. Under the style of response, we understand individual behavior parameter that characterizes the ways of human interaction with a variety of complex situations, manifested either in the form of psychological protection from unpleasant experiences, either in the form of constructive activity of the person, aimed at resolving the problems. Response Styles 
are mediate part between stressful events that happen, and their consequences in the form of, for example, anxiety, psychological distress, somatic disorders accompanying protective behavior or characteristic for coping behavior elation and joy of successful problem solving.

We consider that coping behavior is a deliberate change in the individual psychophysiological functions and neuropsychological state as a whole, which is achieved by means of an organized mental activity, mediating choice of mechanisms to counter the negative impacts of information and the development of adequate information and a rough basis of the personality's life activity. Experts, revealing the essence of coping behavior, use the concept "coping strategies". In some theories of coping behavior basic strategies are allocated: problem-solving; search for social support; shunning. Conflict investigators highlight three planes in which there is a realization of coping strategies: behavioral; cognitive; emotional. Types of behavioral coping strategies are divided and based on their degree of adaptive capacity: adaptive, relatively adaptive and maladaptive. We believe that if the coping behavior is the individual conscious strategies to overcome the crisis in accordance with their importance in the life of the individual and psychological capabilities of the individual, then the coping strategy is a combination of cognitive, emotional, behavioral types of personality's activities aimed at overcoming the dangers and threats and ensuring personal safety.

Mechanisms of information-psychological self-defense, implemented in the unconscious, the subconscious, the conscious level

It is found that the mechanisms for information-psychological self-defense are self-contained structural and functional composition, ensuring protection of the individual from the internal psychological discomfort or external psychological impact, contributing to the preservation of psychological homeostasis and stability, causing the formation and functioning of adequate information and a rough basis of life activity (Kara-Murza, 2008). These mechanisms are implemented on three psychological levels. First is the unconscious one, which prevents a person from the negative emotional overload and includes instinctive reflex mechanisms of information-psychological selfdefense. At this level, there are retro-mechanisms - retreat, the self-closing, regression, stunning (Nepomnyaschaya, 2001). Secondly, a subconscious level, which protects a person from the perception of traumatic information, manipulative information impacts, which causes a steady focus on coping behavior and includes unconscious generalized mechanisms of information-psychological self-defense At this level, there are mode-mechanisms (from the Latin modus -. Measure, way, image, view) repression, suppression, asceticism, nihilism, lock, escaping into virtual reality (Posokhova \& Solovjev, 2008). Third, the conscious level, ensuring the creation of strong-willed programs of information-psychological self-defense, and includes selfdefense automatisms (complexes of stereotypically occurring mechanisms of information-psychological self-defense in typical situations - aggression, desacralization, idealization, projection, transformation, humor, emotional burnout, depreciation) formed in the course of information activities, and logical-semantic mechanisms of information-psychological self-defense (identification, role play, inversion, rationalization, intellectualization, compensation, introjections). Thus, based on the psychological levels of implementation of information-psychological mechanisms of self-defense, we have identified retro-mechanisms (the unconscious level), modus-mechanisms (sub-conscious level) and volitional mechanisms (the conscious level) (Konopkin, 2008). 


\section{Criteria for effective mastering the mechanisms of self-government of \\ safe behavior}

The criteria have been identified through the written survey of 500 teachers, 500 students of Kazan State Architectural University. The survey found the attitude of teachers and students to self-management of safe behavior. It was found that $81 \%$ of teachers determine the self-government of safe behavior as the ability to ensure confidence and stability and the security from the dangers and threats. According to $79 \%$ of the students the self-government of safe behavior are self-defense skills and skills from a variety of risks and threats. In practice, according to the students, this is manifested in: a job in a company that provides its employees with social guarantees; trying to save for "rainy day"; the existence of various types of insurance (medical, insurance against job loss or disability, pension insurance). A survey of teachers and students has shown the criteria for effective mechanisms of self-government of safe behavior are: the ability to assess the situation as potentially dangerous, knowledge of the mechanisms of self-government of safe behavior in practice; ability to apply mechanisms of self-government of safe behavior in practice; the desire to be safe, to avoid risks.

\section{Discussions}

A number of studies are devoted to the problem of self-government of safe behavior. Characteristic of security as a basic human need is given in the studies of A.H. Maslow (1959), K. Horney (1991), H.L. Murray (2007). In the works of B. Schneier (2003), a process of risk perception is studied. In the works of G.G. Verbina (2013), N.S. Yefimova (2010) the concept of "psychological security of the person" is scientifically proven. Mechanisms of security protection in social conflicts are revealed in the works of G.V. Grachov (1998), A.V. Manoilo, (2003) F.N. Tsyrdya \& A.D. Ursul (2016). The content of information-psychological safety of the person, as a condition of protection of his or her mind from the action of diverse information factors that impede social behavior of the person is considered in the works of V.S. Grekhnev (2006), G.B. Parshukova (2006), L.A. Pronina (2008). In the writings of O.A. Konopkin (2005) the characteristic of psychic self-regulation is given, as the independent making of interrelated decisions, the implementation of the agreed sequence with each other (Konopkin, 2005; Konopkin, 2008) Works of L.I. Antsyferova (1994) investigate the dynamics of consciousness and actions of personality in difficult life circumstances as the result of mental processing by the individual of ills of life from the standpoint of their own, only partially perceived "theory" of the world. The essence of copingbehavior is the subject of investigations of a whole group of authors (Folkman, Schaefer \& Lazarus, 1979; Lasarus \& Folkman, 1984; Moss \& Schaefer, 1986; Ebata \& Moos, 1991; Bouchard, Guillemette \& Landry-Leger, 2004; Brown, Westbrook \& Challagalla, 2005; Lasarus, 2006; Ivanov \& Garanyan, 2010) Analysis of the works of the above mentioned authors showed that in the sphere of security along with the instincts a major role belongs to the attitude to the situation. In critical, extreme situations, the need for security acts as an active force, prompting the body to mobilize all resources to deal with the threat. However, the mechanisms of self-government of safe behavior are not generalized; relationship between the individual attitudes to the security and readiness formation to safe life activity, eliminating of hazards or its reducing to an acceptable level are not established.

\section{Conclusion and Recommendations}


It is found that the security of the person, as an opportunity to live, without exposing themselves to various risks and hazards, is highly valued in human society. This causes the relation of the individual to personal security as a public good, which is a set of material and spiritual values. It is found that the mechanisms of selfgovernment of safe behavior include mechanisms to counter the negative information and psychological impact and mechanisms of information-psychological self-defense. Mechanisms for individual's countering the negative information and psychological influences combine psychological mechanisms of self-regulation, promoting the efficiency of coping behavior as purposeful change in individual psycho-physiological functions and neuropsychological state as a whole, which is achieved by a specially organized mental activity, mediated by the choice of methods for protection of consciousness from the negative information influences and development of adequate information and a rough basis of life. Mechanisms of information-psychological selfprotection combine: (1) retro-mechanisms protecting from negative emotional overload and activating instinctive reflex mechanisms of information-psychological self-defense; 2) mode-mechanisms that protect against the perception of traumatic information, manipulative information impacts, causing a steady focus on coping behavior and activating generalized unconscious mechanisms of informationpsychological self-defense 3) volitional mechanisms, activating self-defense automatisms and logical-semantic mechanisms.

It is found that the mechanisms to counter the negative information and psychological impacts and mechanisms of information-psychological self-defense are dialectically interrelated. The relationship is determined by their functions in the process of self-government of safe behavior. Mechanisms for countering negative information and psychological influences play a compensatory function. Mechanisms of information-psychological self-defense - de-compensatory function. Coping behavior is used as a strategy for actions of the individual, aimed at addressing the situation of psychological threat. This leads to two styles of response to dangers and threats: problem-oriented (problem-focused) (a rational analysis of the problems associated with the creation and implementation of a plan to resolve it, the use of coping strategies) and subjectively oriented (emotion-focused) (emotional reaction to a situation that is not accompanied by concrete actions, the use of mechanisms of information -psychological self-defense). Preference in response style depends on the particular hazard or threat.

In the view of the results we can identify a number of scientific issues for identity's safety management that require further consideration: the influence of individualtypological features of the person on the security of their behavior; selection and structuring of educational material on safe behavior.

\section{Disclosure statement}

No potential conflict of interest was reported by the authors.

\section{Notes on contributors}

Rashad A. Kurbanov - Doctor of Law, Professor, Honored Lawyer of the Russian Federation, Head of the Department of Civil Legal Disciplines, Plekhanov Russian University of Economics, Moscow, Russia.

Ramin Afad oglu Gurbanov - Doctor of Law, Leading specialist of the Department of International Relations and International Law, Institute of Philosophy and Law of National Academy of Sciences of Azerbaijan, Baku, Azerbaijan.

Asiya M. Belyalova - Senior Specialist of the Institute of Legislation and Comparative Law under the Government of the Russian Federation, Moscow, Russia. 
Elvira V. Maksimova - PhD, Associate Professor, Head of International Activities Sector, Kazan (Volga region) Federal University, Kazan, Russia.

Irina A. Leonteva - PhD, Associate Professor, Head of the Department of Management and Marketing, Chuvash State University, Cheboksary, Russia.

Ivan A. Sharonov - PhD, Associate Professor of the Department of Agricultural Technology, Machinery and Safety, Ulyanovsk State Agricultural Academy named after P. A. Stolypin, Ulyanovsk, Russia.

\section{References}

Abulkhanova-Slavskaya, K.A. (1980). Activities and Personality Psychology. Moscow, "Nauka" Publishing House.

Antsyferova, L.I. (1994). Person in difficult conditions: preconception, transformation of situations and psychological protection. Psychological journal, 15, 3-18.

Bouchard, G., Guillemette, A. \& Landry-Leger, N. (2004). Situational and dispositional coping: an examination of their personality, cognitive appraisals and psychological distress. European Journal of Personality, $18,221-238$.

Brown, S.P., Westbrook, R.A. \& Challagalla, G. (2005). Good Cope, Bad Cope: Adaptive and maladaptive doping strategies following a critical negative work event. Journal of applied psychology, 4, 982-798.

Ebata, A. \& Moos, T. (1991). Coping and adjustment in distressed and healthy adolescents. Journal of Applied Developmental Psychology, 12, 33-54.

Folkman, S., Schaefer, C. \& Lazarus, R. (1979). Cognitive Processes as Mediators of Stress and Coping. Human Stress and Cognition.Chapter, 9, 265-298.

Grachov, G.V. (1998). Information-psychological security of the person: the condition and the possibility of psychological protection. Moscow: Publishing House of the RASA.

Grekhnev, V.S. (2006). Information society and education. Bulletin of Moscow University. Series 7. Philosophy, 6, 88-106.

Horney, K. (1991). Final Lectures, ed. Douglas H. Ingram. New York: W. W. Norton.

Horney, K. (2000). Our internal conflicts. Moscow: April-Press, Publishing house Eksmo-Press.

Ivanov, P.A. \& Garanyan, N.G. (2010). Testing of the questionnaire of coping strategies (COPE). Psychological Science and Education, 1, 82-93.

Kara-Murza, S.G. (2008). Manipulation of consciousness. Moscow: Eksmo.

Konopkin, 0.A. (2005). Structural and functional and content-psychological aspects of self-conscious. Psychology. Journal of Higher School of Economics, 1, 27-42.

Konopkin, O.A. (2008). Conscious self-regulation as a criterion of subjectivity. Questions of Psychology, 3, 2234.

Kuznetsov, S.A. (2000). Great Dictionary of Russian language. St. Petersburg: Ripol-Norint.

Lasarus, R. (2006). Emotions and interpersonal relationships: toward a person-centered conceptualization of emotions and coping. Journal of Personality, 74, 9-43.

Lasarus, R. \& Folkman, S. (1984). Stress, appraisal and coping. New York: Springer.

Maslow, A.H. (1959). New Knowledge in Human Values. New York: Harper \& Row.

Leontjev, A.N. (1975). Activities. Consciousness. Personality. Moscow: Politizdat.

Lunev, A.N. \& Pugacheva, N.B. (2013), Historical forms of state, family and private education. Sociology, Psychology, Pedagogy, 4, 11-16.

Lunev, A.N. \& Pugacheva, N.B., (2014). Information-psychological security of the person: philosophical aspect. Society: Philosophy, History, Culture, 1, 11-16.

Lunev, A.N., Pugacheva, N.B. \& Stukolova, L.Z. (2014), Strategies and trends of municipal educational system development. Scientific-Methodical Electronic Journal Concept, 3, 14-60.

Manoilo, A.V. (2003). State information policy in special circumstances. Moscow: Moscow Engineering Physics Institute.

Moss, R.H. \& Schaefer, J.A. (1986). Life transitions and crises.Coping with life crises.An integrative approach. New York: Plenum Press.

Murray, H.L. (2007).Explorations in Personality. New York: Oxford Academ.

Nepomnyaschaya, N.I. (2001). Psycho-diagnostic study of personality: Theory and Practice. Moscow: Publishing Center for Humanities VLADOS. 
Parshukova, G.B. (2006). Information competence of the individual. Diagnostics and formation. Novosibirsk: Novosibirsk State Technical University Publishing House.

Petrova, T.N., Kirillova, O.V., Sokolova, S.G., Pugacheva, N.B., Galimullina, A.F., Maksimova, O.G., Antonova, T.V. \& Kozhanov, V.V. (2016). Education as the Management of Research Universities Students' Socialization. International Review of Management and Marketing, 6(2), 28-33.

Petrovsky, A.V. \& Yaroshevskiy, M.G. (2001). Theoretical psychology. Moscow: Academy.

Posokhova, S.T. \& Solovjeva, S.L. (2008). Handbook of Practical Psychology. Moscow: AST.

Pronina, L.A. (2008). Information technology in the preservation of cultural heritage. Analysis of Cultural Studies, 12, 75-78.

Pugacheva, N.B., Ezhov, S.G., Kozhanov, I.V., Kozhanova, M.B., Ogorodnikova, S.V., Oshaev, A.G., Timonin, A.I. \& Goloshumova, G.S. (2016). The model of self-realization readiness formation of research universities students in the process of civic education. International Review of Management and Marketing, 6, 128133.

Schneier, B. (2003). Beyond Fear: Thinking Sensibly about Security in an Uncertain World. NewYork: CopernicusBooks.

Tsygankov, P.A. (2010). Human security in the context of international politics: theory and practice questions. Proceedings of scientific seminar. Moscow: Moscow State University.

Tsyrdya, F.N. \& Ursul, A.D. (2016). Information security of the person as a decisive factor in human survival strategy. Direct access: http://security.ase.md/publ/ru/pubru23.html

Verbina, G.G. (2013). Psychological security of the person. Bulletin of Chuvash University, 4, 196-202.

Wasserman, L.I., Iovlev, B.V., Isaeva, E.R., Trifonova, E.A., Schelkova, O.Yu., Novozhilova, M.Yu. \& Vuks, A.Ya. (2009). Methods of psychological diagnostics methods of coping with stressful and problematic situations for the individual. St. Petersburg: Publishing house of Psycho-neurological Research Institute named after Bekhterevp.

Yefimova, N.S. (2010). Bases of psychological security. Moscow: ID FORUM: INFRA-M p. 